\title{
$\beta$-Amyloid Immunotherapy Prevents Synaptic Degeneration in a Mouse Model of Alzheimer's Disease
}

\author{
Manuel Buttini, ${ }^{1}$ Eliezer Masliah, ${ }^{2}$ Robin Barbour, ${ }^{1}$ Henry Grajeda, ${ }^{1}$ Ruth Motter, ${ }^{1}$ Kelly Johnson-Wood, ${ }^{1}$ Karen Khan, ${ }^{1}$ \\ Peter Seubert, ${ }^{1}$ Stephen Freedman, ${ }^{1}$ Dale Schenk, ${ }^{1}$ and Dora Games ${ }^{1}$ \\ ${ }^{1}$ Elan Pharmaceuticals, South San Francisco, California 94080, and ${ }^{2}$ Departments of Neurosciences and Pathology, University of California at San Diego, La \\ Jolla, California 92093
}

\begin{abstract}
Alzheimer's disease neuropathology is characterized by key features that include the deposition of the amyloid $\beta$ peptide (A $\beta$ ) into plaques, the formation of neurofibrillary tangles, and the loss of neurons and synapses in specific brain regions. The loss of synapses, and particularly the associated presynaptic vesicle protein synaptophysin in the hippocampus and association cortices, has been widely reported to be one of the most robust correlates of Alzheimer's disease-associated cognitive decline. The $\beta$-amyloid hypothesis supports the idea that $\mathrm{A} \beta$ is the cause of these pathologies. However, the hypothesis is still controversial, in part because the direct role of $\mathrm{A} \beta$ in synaptic degeneration awaits confirmation. In this study, we show that $\mathrm{A} \beta$ reduction by active or passive $\mathrm{A} \beta$ immunization protects against the progressive loss of synaptophysin in the hippocampal molecular layer and frontal neocortex of a transgenic mouse model of Alzheimer's disease. These results, substantiated by quantitative electron microscopic analysis of synaptic densities, strongly support a direct causative role of $A \beta$ in the synaptic degeneration seen in Alzheimer's disease and strengthen the potential of $A \beta$ immunotherapy as a treatment approach for this disease.
\end{abstract}

Key words: synapses; vaccination; Alzheimer's disease; amyloid; neurodegeneration; transgenic mice; amyloid protein precursor

\section{Introduction}

Alzheimer's disease $(\mathrm{AD})$ is an age-dependent neurodegenerative disease characterized by progressive cognitive decline and morphological CNS alterations, such as deposition of the amyloid peptide $[\beta$-amyloid $(\mathrm{A} \beta)]$ in parenchymal plaques and cerebral blood vessels, intraneuronal formation of neurofibrillary tangles, and loss of neuronal subpopulations in specific brain regions (Terry et al., 1991). The loss of synapses and of the associated presynaptic protein synaptophysin (SYN) is another cardinal feature of AD and strongly correlates with cognitive decline (DeKosky and Scheff, 1990; Masliah et al., 1991; Terry et al., 1991; Dickson et al., 1995; Terry, 1996; Sze et al., 1997; Scheff and Price, 2003) In contrast, the relationship between amyloid plaques and cognitive decline remains controversial (Terry, 1996; Davis and Chisholm, 1997; Klein et al., 2001).

Transgenic mice that neuronally express human $A \beta$ precursor protein (hAPP mice) carrying mutations associated with familial autosomal dominant forms of $\mathrm{AD}$ develop $\mathrm{A} \beta$ plaques and neuritic dystrophy similar to those found in AD (Games et al., 1995; Masliah et al., 1996). Such mouse models have been useful to investigate emergent therapies aimed at the reduction of $A \beta$. In particular, $\mathrm{A} \beta$-based immunotherapy has been shown to be effi-

Received Nov. 17, 2004; revised Aug. 8, 2005; accepted Aug. 17, 2005

We thank Minh Nguyen, T. Guido for technical assistance, Drs. N. Vasquez and G. Basi for reagents, Dr. S. Schroeter for help with graphics, and Dr. F. Bard for critical reading of this manuscript.

Correspondence should be addressed to Dr. Manuel Buttini, Elan Pharmaceuticals, 800 Gateway Boulevard, South San Francisco, CA 94080. E-mail: manuel.buttini@elan.com.

D0I:10.1523/JNEUROSCI.1697-05.2005

Copyright $\odot 2005$ Society for Neuroscience $\quad$ 0270-6474/05/259096-06\$15.00/0 cacious in reducing amyloid-associated pathology in several hAPP-transgenic mice (Schenk et al., 1999; DeMattos et al., 2001; Sigurdsson et al., 2001).

Synaptic loss and/or dysfunction have also been described in some hAPP-transgenic mouse lines (Games et al., 1995; Mucke et al., 2000). Previous studies involving $A \beta$ immunotherapy and using hAPP mice focused primarily on amyloid deposition and plaque-associated pathology (Schenk et al., 1999; Bussiere et al., 2004) but did not examine the effect of immunotherapy-induced $\mathrm{A} \beta$ reduction on loss of synapses.

Therefore, it is important to determine whether $A \beta$ reduction after $A \beta$ immunotherapy prevents synaptic degeneration in hAPP mice, thus further validating the amyloid hypotheses of AD pathogenesis (Hardy and Selkoe, 2002).

\section{Materials and Methods}

Generation of $A \beta, A \beta$ fragments, and monoclonal anti-A $\beta$ antibodies. $\mathrm{A} \beta(1-42)$ was generated as described previously (Schenk et al., 1999). $\mathrm{A} \beta$ peptides corresponding to $\mathrm{A} \beta(1-5), \mathrm{A} \beta(3-9)$, and $\mathrm{A} \beta(15-24)$ and the reverse sequence $A \beta(5-1)$ were synthesized contiguous to a 17 aa T-cell epitope derived from ovalbumin (amino acids 323-339, ISQAVHAAHAEINEAGR) on a branched peptide framework (triplelysine core with four peptide arms) to produce a multiantigen peptide as described previously (Bard et al., 2003). The peptides were synthesized by AnaSpec (San Jose, CA). The IgG2a isotype monoclonal anti-A $\beta$ antibodies 3D6 [anti-A $\beta(1-5)$ ] and 12B4 [anti-A $\beta(3-7)$ ] were generated as described previously (Seubert et al., 1992; Bard et al., 2003).

Passive and active immunization procedures. Twelve- to 13-month-old heterozygous PDAPP mice and nontransgenic littermate controls were used. PDAPP mice express human, mutated (V717F) hAPP under the control of the platelet-derived growth factor promoter (Games et al., 

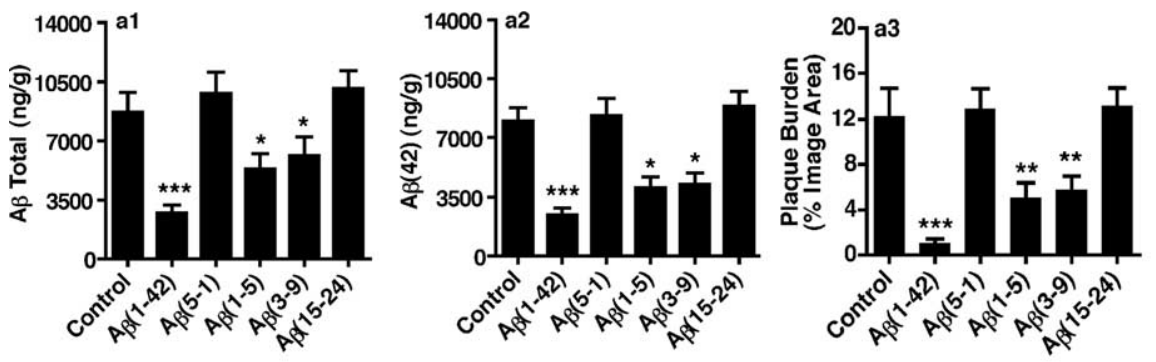

immunization with $\mathrm{A} \beta$ fragments, $100 \mu \mathrm{g}$ of an $\mathrm{A} \beta$ fragment in complete Freund's adjuvant was injected intraperitoneally, followed by boosts with $100 \mu \mathrm{g}$ of the $\mathrm{A} \beta$ fragment in incomplete Freund's adjuvant at 2 and 4 weeks, and monthly thereafter. Control PDAPP mice received injections of MPL-SE adjuvant alone or Freud's adjuvant with $A \beta(5-1)$. For passive immunization, antibodies dissolved in PBS were injected intraperitoneally at $\leq 10 \mathrm{mg} / \mathrm{kg}$ each week for 6 months. Control PDAPP mice received equivalent injections of an irrelevant
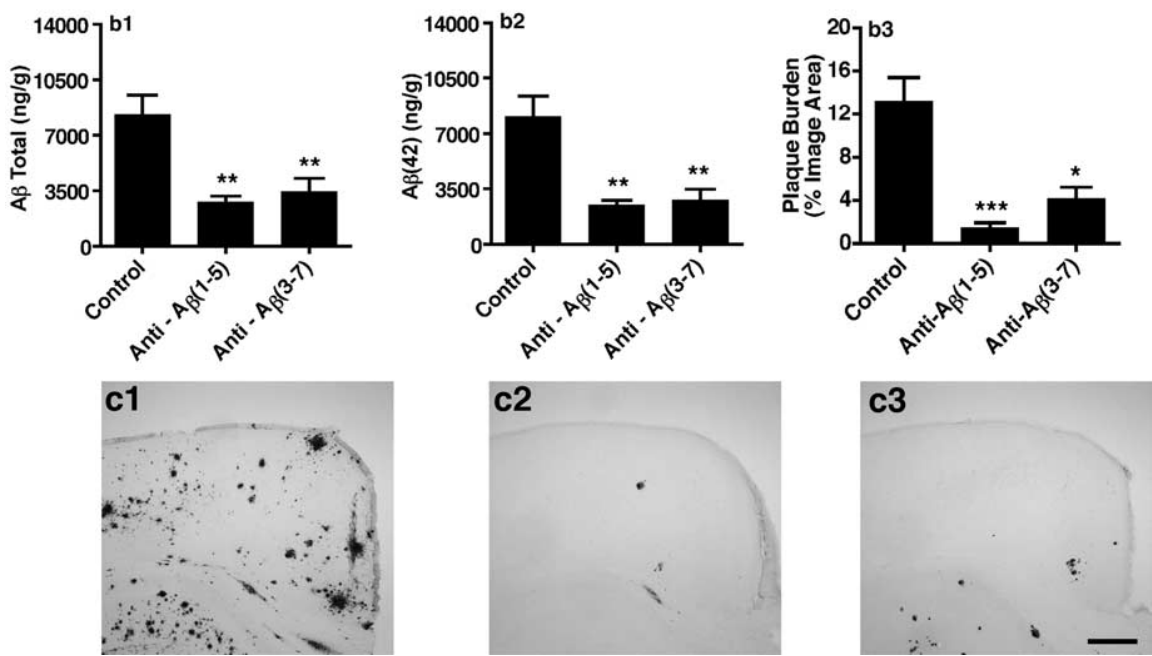

Figure 1. Active and passive $A \beta$ immunization reduced $A \beta$ levels and plaque burden in brains of the PDAPP mice. Brains of actively immunized ( $\boldsymbol{a} 1-\boldsymbol{a} 3)$, passively immunized $(\boldsymbol{b} \mathbf{1}-\boldsymbol{b} \mathbf{3})$, and control PDAPP mice were processed for measurements of total $A \beta(\boldsymbol{a} 1, \boldsymbol{b} 1)$ and $A \beta(42)(\boldsymbol{a} \mathbf{2}, \boldsymbol{b} 2)$ in the cortex by ELISA, or for measurement of plaque burden in the frontal neocortex $(\boldsymbol{a} \mathbf{3}, \boldsymbol{b} \boldsymbol{3}$, c1-c3) by quantitation of immunoperoxidase-stained brain sections (see Materials and Methods). Active immunization, either with full-length $A \beta(1-42)$ or with $N$-terminal $A \beta$ fragments, and passive immunization with $N$-terminal $A \beta$ antibodies reduced levels of total $A \beta$ and of $A \beta(42)$ in the cortex of PDAPP mice. Similar results were obtained for the hippocampus (data not shown). The plaque burden in the frontal neocortex and hippocampus of a PDAPP mouse treated with either adjuvant alone (Control; $c 1$ ), full-length $A \beta(1-42)$ (Active; $c 2$ ), or anti-A $\beta(1-5)$ (Passive; $c 3$ ) is shown. The results shown are means \pm SEM. ${ }^{*} p<0.05$, ${ }^{* *} p<0.01,{ }^{* * *} p<0.001$ (nonparametric Dunn's post hoc test; $n=16-25$ mice per group). Scale bar, $0.3 \mathrm{~mm}$.

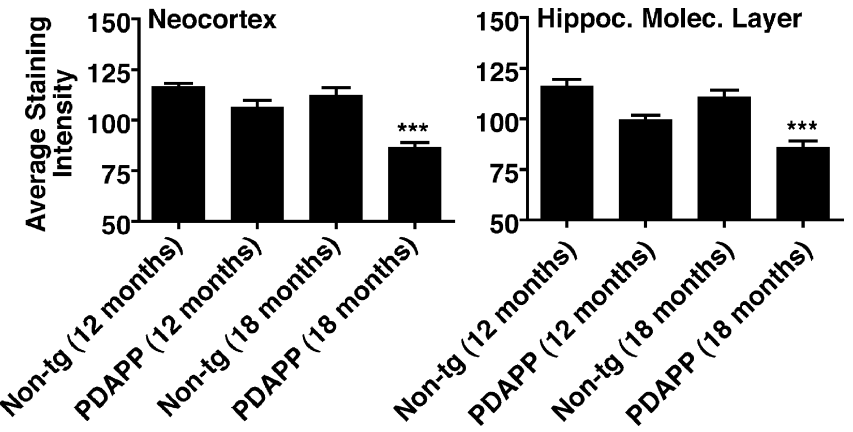

Figure 2. Synaptic degeneration in PDAPP mice was age dependent. SYN-positive presynaptic terminal levels in the frontal neocortex (left) and hippocampal OML (Hippoc. Molec. Layer; right) of PDAPP mice and nontransgenic (Non-tg) littermate controls are shown. SYN levels were determined in immunofluorescent-labeled brain sections from 12- and 18-month-old PDAPP mice, as described in Materials and Methods. A significant SYN decrease was seen at 18 months, but not at 12 months, in both brain regions. The results shown are means \pm SEM. ${ }^{* * *} p<0.001$ (Tukey's post hoc test; $n=10-17$ mice per group).

1995). All mice were of the Swiss-Webster background, and experiments were performed in accordance with Institutional Animal Care and Use Committee policies and procedures. For active immunization with $\mathrm{A} \beta(1-42), 100 \mu \mathrm{g}$ of $\mathrm{A} \beta(1-42)$ in an emulsion formulation of monophosphoryl lipid A (MPL-SE) adjuvant was injected intraperitoneally, followed by boosts at 2 and 4 weeks, and monthly thereafter. For active isotyped-matched antibody or of PBS only. At the end of all treatments, mice were killed and perfused transcardially with PBS. Nontransgenic, age- and strain-matched mice were processed in the same manner. The brains were quickly removed and fixed for $48 \mathrm{~h}$ in phosphate-buffered $4 \%$ paraformaldehyde before being processed for immunohistochemistry.

Quantitation of $A \beta$ levels and plaque burden. Snap-frozen cortices and hippocampi were homogenized in guanidine buffer, and levels of total $A \beta$ and of $A \beta(42)$ were quantitated by ELISA as described previously (Johnson-Wood et al., 1997). Plaque burden was assessed by quantitative immunoperoxidase histochemistry on $40 \mu \mathrm{m}$ free-floating vibratome sections using the monoclonal anti-A $\beta$ antibody $3 \mathrm{D} 6$, as described previously (Schenk et al., 1999; Bard et al., 2000). Six immunolabeled sections were analyzed per mouse, and the average of the individual measurements was used to calculate group means.

Quantitative SYN immunohistochemistry. Forty-micrometer free-floating sections were immunostained with 1:850-diluted anti-SYN antibody (clone SY38; Dako, Carpenteria, CA) and FITC-labeled secondary antibody following a standard protocol. Immunolabeled brain sections were assigned code numbers to ensure objective assessment and imaged with a BioRad (Hercules, CA) MRC-1024 laser scanning confocal microscope, mounted on a Nikon (Melville, NY) Optiphot-2 microscope and running Lasersharp software, as described previously (Masliah et al., 1992; Buttini et al., 1999). SYN levels were assessed in the frontal neocortex and the hippocampal outer molecular layer (OML) in two sections per animal (Buttini et al., 1999). For each mouse, we obtained four confocal images (two per section) of the neocortex and two confocal images (one per section) of the hippocampal OML, each covering an area of $240 \times$ $180 \mu \mathrm{m}$. The iris and gain levels were adjusted to obtain images with a pixel intensity within a linear range. Digitized, eight-bit images were transferred to a Macintosh computer, and the average pixel intensity of SYN staining was calculated for each image with NIH Image. For each mouse, the values obtained for the frontal neocortex or the hippocampal OML were averaged. This approach for the assessment of synaptic degeneration has been validated in various experimental models of neurodegeneration (Buttini et al., 1999; Mucke et al., 2000) and in diseased human brains (Masliah et al., 1992).

Electron microscopy. Some vibratome sections were postfixed with $4 \%$ paraformaldehyde and $1 \%$ glutaraldehyde in $0.1 \mathrm{M}$ cacodylate buffer, $\mathrm{pH}$ 7.4. Then the sections were immersed in $1 \%$ osmium tetroxide and stained with saturated uranyl acetate dissolved in 50\% ethanol. They were finally dehydrated through a graded series of ethanol to $90 \%$ ethanol; 2-hydroxypropyl methacrylate was the intermediate solvent. All infiltrations of 2-hydroxypropyl methacrylate and Scipoxy 812 resin (Energy Beam Sciences, Agawam, MA) were performed on a shaker at slow speed. After two changes of $100 \%$ resin, the plates were polymerized in a $65^{\circ} \mathrm{C}$ oven for $24 \mathrm{~h}$. The plastic was detached, and selected areas were cut 
and glued onto dummy blocks. Thin sections

$(80 \mathrm{~nm})$ were cut on a Reichert Ultracut E Ultramicrotome (Leica, Vienna, Austria), picked up onto 200-mesh copper grids (Electron Microscopy Sciences, Fort Washington, PA), and poststained in ethanolic uranyl acetate, followed by bismuth nitrite (Electron Microscopy Sciences). The sections were analyzed with a Zeiss (Thornwood, NY) EM10 electron microscope. For morphometric analysis of synapses from each section, a total of 20 electron micrographs of the frontal cortical area were obtained at a final magnification of $12,000 \times$. Electron micrographs were digitized and analyzed with the Quantimet 570C (Leica, Deerfield, IL) to determine the density of synapses per unit of volume.

Statistical analyses. Parametric data were analyzed by one-way ANOVA, followed by Dunnett's test or Tukey's multiple comparison test when appropriate. Nonparametric data were analyzed by the Kruskal-Wallis test, followed by Dunn's test for comparison of multiple data sets. Correlation analyses between two data sets were done by Pearson's test if the two data sets were parametric or with Spearman rank correlation if at least one data set was nonparametric. A $p<0.05$ was considered significant. All analyses were done with the Prism software (Graph Pad, San Diego, CA).

\section{Results}

To study the effect of $A \beta$ reduction on synaptic integrity, we used transgenic mice carrying a $\mathrm{V} \rightarrow \mathrm{F}$ (717)-mutated hAPP under the transcriptional control of the PDGF promoter (PDAPP mice) (Games et al., 1995). We immunized PDAPP mice either actively with $A \beta$ peptides or passively with anti-A $\beta$ antibodies for 6 months, using treatments that reliably reduce both $\mathrm{A} \beta$ levels and overall plaque burden in the brain of PDAPP mice (Schenk et al., 1999; Bard et al., 2000, 2003).

First, we confirmed that the immunization treatments led to a significant reduction in $\mathrm{A} \beta$ pathology in the present cohort of PDAPP mice. As reported previously (Bard et al., 2003), we found that levels of total $A \beta$ and of $\mathrm{A} \beta(42)$, as well as plaque burden, were significantly reduced by the active immunization with full-length $\mathrm{A} \beta[\mathrm{A} \beta(1-42)]$ or $\mathrm{N}$-terminal $\mathrm{A} \beta$ fragments (Fig. 1a1-a3) and after passive immunization with $\mathrm{N}$-terminal $\mathrm{A} \beta$ antibodies (Fig. 1b1-b3). Consistent with previous results (Bard et al.,

2003), we observed the most prominent reductions in plaque burden (90\% on average) after immunizations with full-length $\mathrm{A} \beta$ $[\mathrm{A} \beta(1-42)]$ or with an antibody against $\mathrm{A} \beta(1-5)$ (Fig. $1 c 1-c 3)$.

We then analyzed SYN levels in the frontal neocortex and hippocampal OML of untreated PDAPP mice and littermate controls at 12 and 18 months of age by confocal microscopy and computer-assisted image analysis (Buttini et al., 1999). Compared with nontransgenic controls, a significant decrease in SYN $50 \mu \mathrm{m}$.
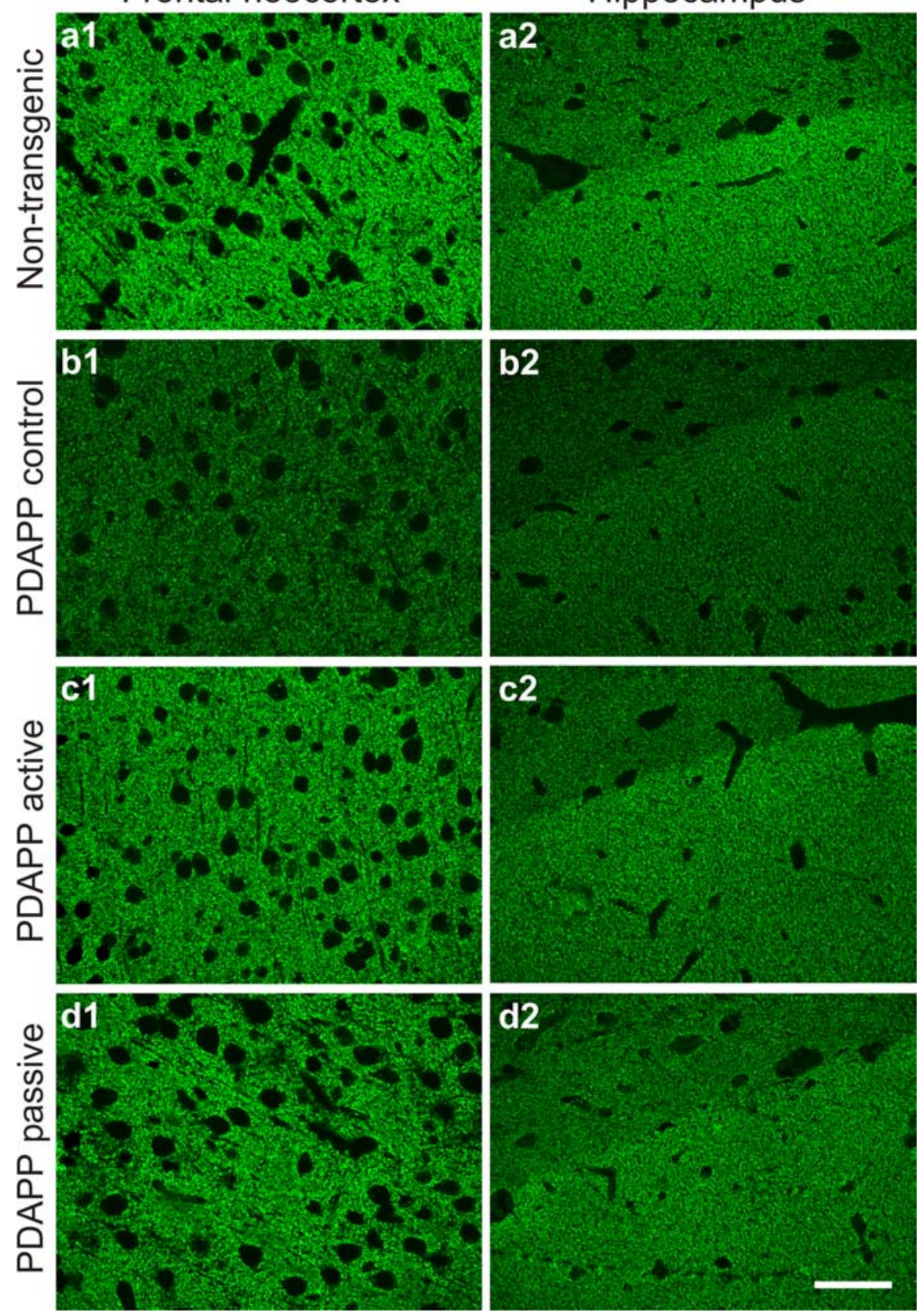

Figure 3. $\quad A \beta$ immunization prevented synaptic degeneration in PDAPP mice. The images show SYN-positive presynaptic terminals in the frontal neocortex (left) and hippocampal 0ML (right) from an 18-month-old nontransgenic mouse (a1, a2), a control-treated PDAPP mouse (b1, b2), an actively immunized $[A \beta(1-42)]$ PDAPP mouse (c1, $\mathbf{c})$, and a passively immunized (3D6) PDAPP mouse (d1, d2). Portions of two hippocampal subregions are visible in the right panels: the OML with a high synaptic density appears bright, and the stratum lacunosum with a lower synaptic density appears darker. Hippocampal SYN measurements were done in the OML. Note that SYN levels in immunized PDAPP mice are similar to those of nontransgenic mice. Scale bar,

was observed in the frontal neocortex (Figs. 2, left, 3) and the hippocampal OML (Figs. 2, right, 3) (Games et al., 1995) of 18month-old, but not 12-month-old, PDAPP mice, indicating that synaptic degeneration in these mice was age dependent.

To investigate the effect of immunization-mediated $\mathrm{A} \beta$ reduction on synaptic integrity, we quantified the level of SYN in the frontal neocortex and the hippocampal OML of immunized and control PDAPP mice. Active immunization, with either the full-length $A \beta$ or with $N$-terminal $A \beta$ fragments, prevented SYN 

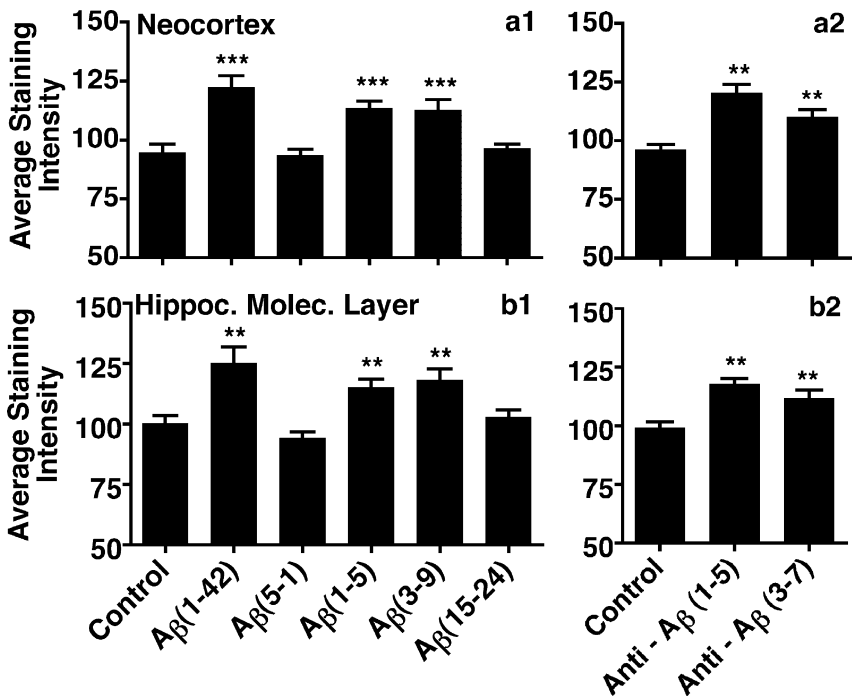

Figure 4. Active and passive $A \beta$ immunizations prevented SYN loss in the frontal neocortex and hippocampal OML (Hippoc. Molec. Layer) of PDAPP mice. For active immunization, 12month-old PDAPP mice were treated with full-length $A \beta[A \beta(1-42)]$ or with different $A \beta$ fragments conjugates $[A \beta(1-5), A \beta(3-9), A \beta(15-24)]$ for 6 months, as described in Materials and Methods. Control PDAPP mice received either vehicle only or a reverse peptide, $A \beta(5-1)$. For passive immunization, 12-month-old PDAPP mice were treated for 6 months with either $3 D 6$ [directed against $A \beta(1-5)$ ] or $12 B 4$ [directed against $A \beta(3-7)$ ], dosed at $10 \mathrm{mg} / \mathrm{kg}$ for each weekly injection as described in Materials and Methods. Control PDAPP mice received injections of an irrelevant antibody or vehicle only. All antibodies were of the lgG2a isotype. SYN levels were analyzed in the frontal neocortex and hippocampal OML of 18-month-old PDAPP mice after completion of immunization. Significant improvements of SYN levels over controls were found after active immunization with $A \beta(1-42), A \beta(1-5)$, and $A \beta(3-9)$, but not $A \beta(15-24)(\boldsymbol{a} 1, \boldsymbol{b} 1)$, and after passive immunization with either of two $\mathrm{N}$-terminal $A \beta$ antibodies $(\boldsymbol{b} 1, \boldsymbol{b} 2)$. In these groups, SYN levels were not significantly different from that of nontransgenic mice or 12-month-old untreated PDAPP mice (see Figs. 2, 3). The results shown are means \pm SEM. ${ }^{* *} p<0.01,{ }^{* * *} p<0.001$, by Dunnett's post hoc test $(n=16-25$ mice per group).

loss in PDAPP mice (Figs. $3 c 1, c 2,4 a 1, b 1$ ). Immunization with immunoconjugates targeting the central region of $\mathrm{A} \beta$, despite inducing $A \beta$ antibody titers that were at least as high as after immunization with $\mathrm{N}$-terminal conjugates (data not shown), did not protect against SYN loss.

To confirm that this effect was specifically mediated by antibodies directed to $\mathrm{A} \beta$, we passively immunized PDAPP mice with anti-A $\beta$ antibodies directed against the $\mathrm{N}$-terminal portion of $\mathrm{A} \beta$. We found that passive immunization with these $\mathrm{A} \beta$ antibodies was synaptoprotective (Figs. $3 d 1, d 2,4 a 2, b 2$ ). SYN levels in PDAPP mice that had been passively immunized with $10 \mathrm{mg} / \mathrm{kg}$ weekly doses of 3D6 (directed against $\mathrm{A} \beta$ epitope $1-5$ ) or $12 \mathrm{~B} 4$ (directed against $\mathrm{A} \beta$ epitope 3-7) were similar to those of nontransgenic mice (Figs. 3, 4). Immunization with weekly doses as low as $1 \mathrm{mg} / \mathrm{kg}$ of 3D6 was synaptoprotective, but lower weekly doses $(0.3$ and $0.1 \mathrm{mg} / \mathrm{kg}$ ) were not (data not shown), demonstrating a dose-dependent effect.

To determine whether SYN levels were associated with $\mathrm{A} \beta$ plaque burden levels, we correlated SYN levels in control groups and the combined immunized groups of mice with plaque burden. Amyloid plaque burden was measured by quantitation of immunoperoxidase-stained brain section as described previously (Bard et al., 2000, 2003). We found no correlation between SYN levels and amyloid plaque burden (Fig. 5). This indicates that the SYN deficits are not reflected by $\mathrm{A} \beta$ deposition in PDAPP mice.

To confirm that quantitative confocal analysis of SYN levels accurately documented the synaptic integrity of the neuropil, we
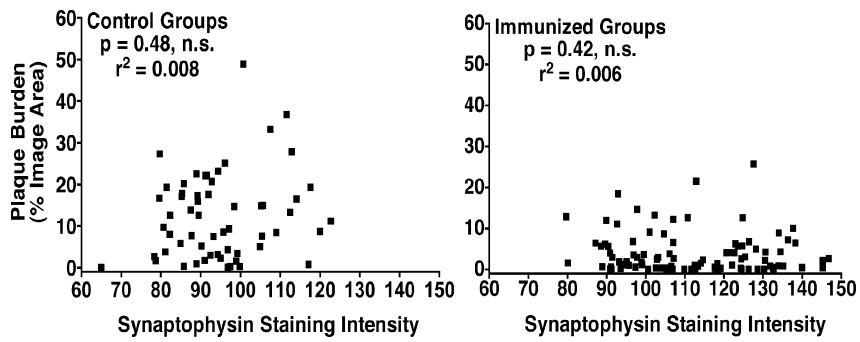

Figure 5. SYN levels did not correlate with $A \beta$ plaque burden. Correlation analyses were performed to determine whether loss of SYN correlated with plaque burden (both measured by quantitative immunohistochemistry; see Materials and Methods) in the frontal neocortex of PDAPP mice. To enhance the power of the analyses, all mice from the control groups of both active and passive immunization were grouped $(\boldsymbol{a})$, and all mice from immunized groups that showed improvements of SYN levels over controls were grouped $(\boldsymbol{b})$. There was no correlation between SYN levels and plaque burden in both cases. Similar results were obtained for the hippocampal OML (data not shown). This finding indicates that, in PDAPP mice, synapse loss is not reflected by measurements of total $A \beta$ plaque burden. $\boldsymbol{a}, p=0.48, r=0.008, n=58$ mice; $\boldsymbol{b}, p=0.42, r=-0.006, n=95$ mice. n.s., Not significant by Spearman rank correlation.

performed ultrastructural analysis on sections from selected brains for which SYN levels were obtained previously. Synaptic densities in sections from control-treated and actively immunized PDAPP mice, as well as from age- and strain-matched nontransgenic mice, were evaluated by quantitative electron microscopy and correlated with SYN levels. Because only a limited number of samples can be analyzed with this approach, sections from brains with SYN levels equal or below the group mean were chosen for the control PDAPP groups, and sections from brains with SYN levels equal or above the group mean were chosen for the immunized PDAPP groups and the nontransgenic mice. Sections from these animals were coded to ensure blinded, objective assessment of synaptic densities, and the codes were not broken until the analysis was complete. In this subset of animals, we found that active immunization of PDAPP mice with full-length $A \beta$ or with $N$-terminal $A \beta$ fragments protected against loss of synaptic densities (Fig. 6a,b). More importantly, our analysis showed that the SYN levels determined by confocal imaging correlated significantly with the number of synaptic densities measured by ultrastructural analysis across all of the animals, regardless of treatment group $\left(r^{2}=0.37 ; p=0.009\right.$ by Pearson's correlation) (Fig. 6c). This finding indicates that quantification of SYN levels by confocal microscopy and quantitative image analysis is an accurate reflection of the number of synaptic densities detected at the ultrastructural level.

\section{Discussion}

In the present study, we demonstrate that synaptic degeneration, a major hallmark of $\mathrm{AD}$ pathology and robust correlate of cognitive decline, is prevented by lowering $A \beta$ levels through $A \beta$ immunotherapy in an AD transgenic mouse model. This finding significantly strengthens the amyloid hypothesis, which states that $\mathrm{A} \beta$ peptide is a primary factor in $\mathrm{AD}$ pathogenesis.

Synaptotoxicity caused by $\mathrm{A} \beta$ may occur through a variety of different mechanisms. Some possibilities include alterations of synaptic function (Walsh et al., 2002; Kamenetz et al., 2003), alterations of ion channel properties (Ye et al., 2003), apoptotic events (Mattson et al., 2001), and oxidative stress (Butterfield and Bush, 2004). Both deposited and nondeposited forms of $\mathrm{A} \beta$ may contribute to the pathogenesis of $\mathrm{AD}$, but their relative contributions to the different $\mathrm{AD}$ pathologies have been difficult to dissect, both in humans and in 
experimental models. In this study, we found that SYN levels did not correlate with total $\mathrm{A} \beta$ plaque burden, indicating that plaque burden does not accurately reflect and is unlikely to predict AD-related synaptic injury in PDAPP mice. Soluble A $\beta$ moieties, such as $\mathrm{A} \beta$ oligomers or protofibrils, may be responsible for synaptic toxicity in PDAPP and other hAPP mice, and, at least in part, in AD (Lambert et al., 1998; Lue et al., 1999; McLean et al., 1999). This hypothesis is supported by findings showing that loss of SYN and impaired synaptic function in other lines of hAPP mice occur before the onset of $\mathrm{A} \beta$ deposition (Hsia et al., 1999; Mucke et al., 2000; Oddo et al., 2003) and that brain injections of medium containing soluble $\mathrm{A} \beta$ moieties inhibit long-term potentiation in rats (Walsh et al., 2002). Plaques, in contrast, haven been reported to disrupt neuronal circuitry and therefore may indirectly affect global synaptic function (Stern et al., 2004) or cognitive function (Chen et al., 2000). Although $\mathrm{A} \beta$ and plaques emerge as the main pathogenic factors in various lines of hAPP mice, other processes not modeled in these mice, such as tau pathology (Goedert, 1999; Johnson and Stoothoff, 2004), vascular pathology (Jellinger, 2005), or aberrant inflamma-

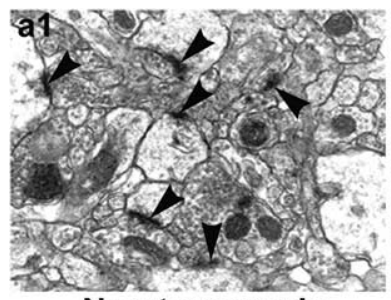

Non-transgenic

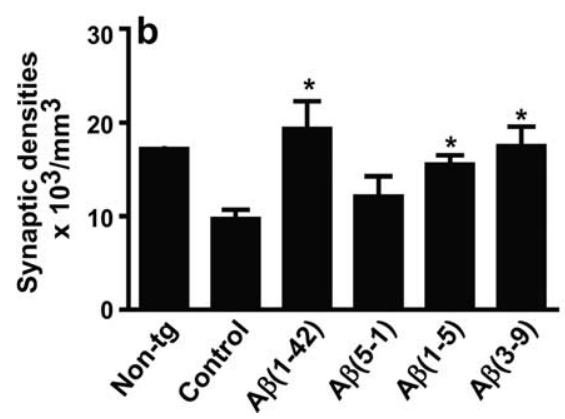

PDAPP control

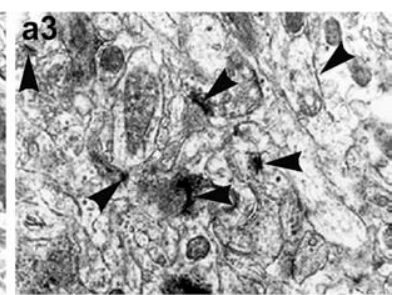

PDAPP immunized

Figure 6. Ultrastructural quantification of neocortical synapses correlated with SYN levels in nontransgenic and in controltreated or immunized PDAPP mice. The images in $\mathbf{a 1 - a 3}$ show electron microscopic images of a neocortical area of a nontransgenic mouse (a1), a control (PBS)-treated PDAPP mouse (a2), and an actively immunized A $\beta(1-5)$ PDAPP mouse (a3). The synaptic densities are marked by arrowheads. Note the diminished number of these densities in the PDAPP control compared with the nontransgenic mouse and the immunized PDAPP mouse. Magnification, $6000 \times$. $\boldsymbol{b}$, The bar graph shows the ultrastructural quantification (see Materials and Methods) of synaptic densities in nontransgenic (Non-tg; $n=2$ mice), control (PBS)-treated $\operatorname{PDAPP}(n=3$ mice per group), and actively immunized $[A \beta(1-42), A \beta(1-5), A \beta(3-9)$, or control A $\beta(5-1)]$ PDAPP $(n=3$ mice per group) mice. Note the significantly higher number of densities in immunized PDAPP mice compared with the two control groups ( ${ }^{*} p<0.05$; Dunnett's post hoc test). $c$, The line graph shows the correlation (Pearson's test) between the ultrastructural quantification of synaptic densities and the SYN levels obtained by quantitative immunohistochemistry (see Materials and Methods). Values from all animals examined by electron microscopy were pooled for the correlation analysis. Note the highly significant correlation between the two endpoints for synaptic integrity.

tion (Wyss-Coray and Mucke, 2002),

may contribute to synaptic and neuronal demise in AD.

Numerous histochemical, biochemical, and quantitative ultrastructural studies have reported significant decreases of synapses and synapse-associated proteins in cortical and hippocampal AD autopsies (DeKosky and Scheff, 1990; Masliah et al., 1991; Terry et al., 1991; Dickson et al., 1995; Terry, 1996; Sze et al., 1997; Scheff and Price, 2003). Of particular interest are studies demonstrating a $25-35 \%$ loss of synaptic densities in $\mathrm{AD}$ brain biopsies that were collected only 2-4 years after clinical diagnosis of the disease (Davies et al., 1987) and other studies showing a significant decrease in SYN immunoreactivity in the hippocampus and association cortices of patients with mild cognitive impairment or mild AD (Masliah et al., 2001). These data strongly indicate that synaptic pathology is an early event in AD. Synaptic loss in AD can occur both as a result of overt neuronal loss and by viable neurons losing their synapses. The latter process may precede the loss of neurons and be of significant consequence to the overall disease process, both pathological and clinically (Scheff and Price, 2003). The most significant and consistent finding across most studies was that the severity of synaptic pathology was a much better correlate of cognitive deficits than were densities of $A \beta$ plaques, tangles, or death of neurons (Terry et al., 1991; Selkoe, 2002). Thus, synaptic pathology emerges as a key pathological phenomenon in $\mathrm{AD}$ relevant to the overall disease process. We have demonstrated here that by reducing $\mathrm{A} \beta$ through active or passive immunization, synaptic pathology in PDAPP mice was prevented. Our observation supports $\mathrm{A} \beta$ immunization as a therapeutic approach that may prevent, at least partially, what is considered the principle correlate of cognitive decline in $\mathrm{AD}$

and establishes $\mathrm{A} \beta$ as one of the principal factors responsible for synaptic demise in this disease.

\section{References}

Bard F, Cannon C, Barbour R, Burke RL, Games D, Grajeda H, Guido T, Hu K, Huang J, Johnson-Wood K, Khan K, Kholodenko D, Lee M, Lieberburg I, Motter R, Nguyen M, Soriano F, Vasquez N, Weiss K, Welch B, et al. (2000) Peripherally administered antibodies against amyloid betapeptide enter the central nervous system and reduce pathology in a mouse model of Alzheimer disease. Nat Med 6:916-919.

Bard F, Barbour R, Cannon C, Carretto R, Fox M, Games D, Guido T, Hoenow K, Hu K, Johnson-Wood K, Khan K, Kholodenko D, Lee C, Lee M, Motter R, Nguyen M, Reed A, Schenk D, Tang P, Vasquez N, et al. (2003) Epitope and isotype specificities of antibodies to beta-amyloid peptide for protection against Alzheimer's disease-like neuropathology. Proc Natl Acad Sci USA 100:2023-2028.

Bussiere T, Bard F, Barbour R, Grajeda H, Guido T, Khan K, Schenk D, Games D, Seubert P, Buttini M (2004) Morphological characterization of thioflavin-S-positive amlyoid plaques in transgenic Alzheimer mice and effect of passive Abeta immunotherapy on their clearance. Am J Pathol 165:987-995.

Butterfield DA, Bush AI (2004) Alzheimer's amyloid beta-peptide (1-42): involvement of methionine residue 35 in the oxidative stress and neurotoxicity properties of this peptide. Neurobiol Aging 25:563-568.

Buttini M, Orth M, Bellosta S, Akeefe H, Pitas RE, Wyss-Coray T, Mucke L, Mahley RW (1999) Expression of human apolipoprotein E3 or E4 in the brains of Apoe-/- mice: isoform-specific effects on neurodegeneration. J Neurosci 19:4867-4880.

Chen G, Chen KS, Knox J, Inglis J, Bernard A, Martin SJ, Justice A, McConlogue L, Games D, Freedman SB, Morris RG (2000) A learning deficit related to age and beta-amyloid plaques in a mouse model of Alzheimer's disease. Nature 408:975-979.

Davies CA, Mann DM, Sumpter PQ, Yates PO (1987) A quantitative morphometric analysis of the neuronal and synaptic content of the frontal and 
temporal cortex in patients with Alzheimer's disease. J Neurol Sci 78:151-164.

Davis II JN, Chisholm JC (1997) The "amyloid cascade hypothesis" of AD: decoy or real McCoy? Trends Neurosci 20:558-559.

DeKosky ST, Scheff SW (1990) Synapse loss in frontal cortex biopsies in Alzheimer's disease: correlation with cognitive severity. Ann Neurol 27:457-464.

DeMattos RB, Bales KR, Cummins DJ, Dodart JC, Paul SM, Holtzman DM (2001) Peripheral anti-A beta antibody alters CNS and plasma A beta clearance and decreases brain A beta burden in a mouse model of Alzheimer's disease. Proc Natl Acad Sci USA 98:8850-8855.

Dickson DW, Crystal HA, Bevona C, Honer W, Vincent I, Davies P (1995) Correlations of synaptic and pathological markers with cognition of the elderly. Neurobiol Aging 16:285-298.

Games D, Adams D, Alessandrini R, Barbour R, Berthelette P, Blackwell C, Carr T, Clemens J, Donaldson T, Gillespie F, Guido T, Hagopian S, Johnson-Wood K, Khan K, Lee M, Leibowitz P, Lieberburg I, Little S, Masliah E, McConlogue L, et al. (1995) Alzheimer-type neuropathology in transgenic mice overexpressing $\mathrm{V} 717 \mathrm{~F}$ beta-amyloid precursor protein. Nature 373:523-527.

Goedert M (1999) Filamentous nerve cell inclusions in neurodegenrative diseases: taupathies and alpha-synucleinopathies. Philos Trans R Soc Lond B Biol Sci 29:1101-1118.

Hardy J, Selkoe DJ (2002) The amyloid hypothesis of Alzheimer's disease: progress and problems on the road to therapeutics. Science 297:353-356.

Hsia AY, Masliah E, McConlogue L, Yu GQ, Tatsuno G, Hu K, Kholodenko D, Malenka RC, Nicoll RA, Mucke L (1999) Plaque-independent disruption of neural circuits in Alzheimer's disease mouse models. Proc Natl Acad Sci USA 96:3228-3233.

Jellinger KA (2005) Understanding the pathology of vascular cognitive impairment. J Neurol Sci 229- 230:57-63.

Johnson GV, Stoothoff WH (2004) Tau phosphorylation in neuronal cell function and dysfunction. J Cell Sci 117:5721-5729.

Johnson-Wood K, Lee M, Motter R, Hu K, Gordon G, Barbour R, Khan K, Gordon M, Tan H, Games D, Lieberburg I, Schenk D, Seubert P, McConlogue L (1997) Amyloid protein precursor and A $\beta 42$ deposition in a transgenic mouse model of Alzheimer's disease. Proc Natl Acad Sci USA 94:1550-1555.

Kamenetz F, Tomita T, Hsieh H, Seabrook G, Borchelt D, Iwatsubo T, Sisodia S, Malinow R (2003) APP processing and synaptic function. Neuron 37:925-937.

Klein WL, Krafft GA, Finch CE (2001) Targeting small Abeta oligomers: the solution to an Alzheimer's disease conundrum? Trends Neurosci 24:219-224.

Lambert MP, Barlow AK, Chromy BA, Edwards C, Freed R, Liosatos M, Morgan TE, Rozovsky I, Trommer B, Viola KL, Wals P, Zhang C, Finch CE, Krafft GA, Klein WL (1998) Diffusible, nonfibrillar ligands derived from Abeta 1-42 are potent central nervous system neurotoxins. Proc Natl Acad Sci USA 95:6448-6453.

Lue LF, Kuo YM, Roher AE, Brachova L, Shen Y, Sue L, Beach T, Kurth JH, Rydel RE, Rogers J (1999) Soluble amyloid beta peptide concentration as a predictor of synaptic change in Alzheimer's disease. Am J Pathol 155:853-862.

Masliah E, Terry RD, Alford M, DeTeresa R, Hansen LA (1991) Cortical and subcortical patterns of synaptophysinlike immunoreactivity in Alzheimer's disease. Am J Pathol 138:235-246.

Masliah E, Achim CL, Ge N, DeTeresa R, Terry RD, Wiley CA (1992) Spectrum of human immunodeficiency virus-associated neocortical damage. Ann Neurol 32:321-329.

Masliah E, Siak A, Mallory M, Mucke L, Schenk D, Games D (1996) Comparison of neurodegenerative pathology in transgenic mice overexpress- ing V717F/ $\beta$-amyloid precursor protein and Alzheimer's disease. J Neurosci 16:5795-5811.

Masliah E, Mallory M, Alford M, DeTeresa R, Hansen LA, McKeel Jr DW, Morris JC (2001) Altered expression of synaptic proteins occurs early during progression of Alzheimer's disease. Neurology 56:127-129.

Mattson MP, Gary DS, Chan SL, Duan W (2001) Perturbed endoplasmic reticulum function, synaptic apoptosis and the pathogenesis of Alzheimer's disease. Biochem Soc Symp 67:151-162.

McLean CA, Cherny RA, Fraser FW, Fuller SJ, Smith MJ, Beyreuther K, Bush AI, Masters CL (1999) Soluble pool of Abeta amyloid as a determinant of severity of neurodegeneration in Alzheimer's disease. Ann Neurol 46:860-866.

Mucke L, Masliah E, Yu GQ, Mallory M, Rockenstein EM, Tatsuno G, Hu K, Kholodenko D, Johnson-Wood K, McConlogue L (2000) High-level neuronal expression of $\mathrm{A} \beta$ 1-42 in wild-type human amyloid protein precursor transgenic mice: synaptotoxicity without plaque formation. J Neurosci 20:4050-4058.

Oddo S, Caccamo A, Shepherd JD, Murphy MP, Golde TE, Kayed R, Metherate R, Mattson MP, Akbari Y, LaFerla FM (2003) Triple-transgenic model of Alzheimer's disease with plaques and tangles: intracellular Abeta and synaptic dysfunction. Neuron 39:409-421.

Scheff SW, Price DA (2003) Synaptic pathology in Alzheimer's disease: a review of ultrastructural studies. Neurobiol Aging 24:1029-1046.

Schenk D, Barbour R, Dunn W, Gordon G, Grajeda H, Guido T, Hu K, Huang J, Johnson-Wood K, Khan K, Kholodenko D, Lee M, Liao Z, Lieberburg I, Motter R, Mutter L, Soriano F, Shopp G, Vasquez N, Vandevert C, et al. (1999) Immunization with amyloid-beta attenuates Alzheimer diseaselike pathology in the PDAPP mouse. Nature 400:173-177.

Selkoe DJ (2002) Alzheimer's disease is a synaptic failure. Science 298:789-791.

Seubert P, Vigo-Pelfrey C, Esch F, Lee M, Dovey H, Davis D, Sinha S, Schlossmacher M, Whaley J, Swindlehurst C, McCormack R, Wolfert R, Selkoe D, Lieberburg I, Schenk D (1992) Isolation and quantification of soluble Alzheimer's beta-peptide from biological fluids. Nature 359:325-327.

Sigurdsson EM, Scholtzova H, Mehta PD, Frangione B, Wisniewski T (2001) Immunization with a nontoxic/nonfibrillar amyloid-beta homologous peptide reduces Alzheimer's disease-associated pathology in transgenic mice. Am J Pathol 159:439-447.

Stern EA, Bacskai BJ, Hickey GA, Attenello FJ, Lombardo JA, Hyman BT (2004) Cortical synaptic integration in vivo is disrupted by amyloid- $\beta$ plaques. J Neurosci 24:4535-4540.

Sze CI, Troncoso JC, Kawas C, Mouton P, Price DL, Martin LJ (1997) Loss of the presynaptic vesicle protein synaptophysin in hippocampus correlates with cognitive decline in Alzheimer disease. J Neuropathol Exp Neurol 56:933-944.

Terry RD (1996) The pathogenesis of Alzheimer disease: an alternative to the amyloid hypothesis. J Neuropathol Exp Neurol 55:1023-1025.

Terry RD, Masliah E, Salmon DP, Butters N, DeTeresa R, Hill R, Hansen LA, Katzman R (1991) Physical basis of cognitive alterations in Alzheimer's disease: synapse loss is the major correlate of cognitive impairment. Ann Neurol 30:572-580.

Walsh DM, Klyubin I, Fadeeva JV, Cullen WK, Anwyl R, Wolfe MS, Rowan MJ, Selkoe DJ (2002) Naturally secreted oligomers of amyloid beta protein potently inhibit hippocampal long-term potentiation in vivo. Nature 416:535-539.

Wyss-Coray T, Mucke L (2002) Inflammation in neurodegenerative disease-a double-edged sword. Neuron 35:419-432.

Ye CP, Selkoe DJ, Hartley DM (2003) Protofibrils of amyloid beta-protein inhibit specific $\mathrm{K}^{+}$currents in neocortical cultures. Neurobiol Dis 13: 177-190. 